\section{The role of oxidative stress in diabetic retinopathy}

BÜLENT GÜRLER, HÜSEYIN VURAL، NEVIN YILMAZ, HALIT OGUZ, AHMET SATICI, NURTEN AKSOY
B. Gürler

H. Oguz

A. Satici

Department of

Ophthalmology

Harran University

Faculty of Medicine

Sanliurfa, Turkey

\section{H. Vural}

N. Aksoy

Department of Biochemistry

Harran University

Faculty of Medicine

Sanliurfa, Turkey

N. Yilmaz

Department of Internal

Medicine

Harran University

Faculty of Medicine

Sanliurfa, Turkey

\section{Dr Bülent Gürler}

Department of

Ophthalmology

Harran University

Faculty of Medicine

Araştirma ve Uygulama

Hastanesi

63200 Sanliurfa, Turkey

Tel: +904143141170

Fax: +90 414315 1181

e-mail: gurlerb@doruk.net.tr

Received: 29 July 1999 Accepted in revised form: 13 April 2000

\section{Abstract}

Purpose To investigate the role of oxidative stress in the development of diabetic retinopathy.

Methods This study included 25 patients with diabetic retinopathy (group I), 34 patients with non-insulin-dependent diabetes mellitus without any angiopathy complications (group II) and 26 healthy subjects (group III). The serum malondialdehyde (MDA)-like metabolite levels as an index of lipid peroxidation, the erythrocyte glutathione peroxidase (GSH-Px), superoxide dismutase (SOD) and serum vitamin $C$ levels of the patients and healthy subjects were measured. Results The mean serum concentration of MDA-like metabolites of patients in group I was $4.38 \pm 1.31 \mathrm{nmol} / \mathrm{ml}$, in group II was $3.38 \pm 0.95 \mathrm{nmol} / \mathrm{ml}$ and in group III was $2.61 \pm 0.85 \mathrm{nmol} / \mathrm{ml}$. There were significant differences between the groups $(p=0.001$ for group I compared with group II, $p=0.0001$ for group I compared with group III and $p=0.002$ for group II compared with group III). There was a significant correlation between the serum lipid peroxidation concentrations and duration of the disease $(r=0.36, p=0.047)$. The mean erythrocyte GSH-Px and SOD levels of group I were respectively $68.97 \pm 18.04$ and $1597.78 \pm 296.46 \mathrm{U} / \mathrm{g} \mathrm{Hb}$, of group II were $64.30 \pm 19.26$ and $1581.33 \pm 278.08 \mathrm{U} / \mathrm{g} \mathrm{Hb}$, and of group III were $65.52 \pm 17.58$ and $1587.44 \pm 281.17 \mathrm{U} / \mathrm{g} \mathrm{Hb}$. There were no significant differences among the antioxidant enzyme levels in the three groups $(p>0.05)$. The mean serum vitamin $C$ level in group $I$ was $42.72 \pm 8.90 \mu \mathrm{mol} / 1$, in group II was $49.26 \pm 11.52 \mu \mathrm{mol} / 1$ and in group III was $58.57 \pm 9.75 \mu \mathrm{mol} / 1$. There were significant differences among the mean serum vitamin $C$ levels of the three groups $(p=0.02$ for group I versus group II $\boldsymbol{p}=\mathbf{0 . 0 0 1}$ for group I versus group III and $p=0.002$ for group II versus group III).

Conclusions Free radicals forming in diabetes mellitus and increasing over time may play a role in the development of diabetic retinopathy, which is an important complication of the disease.
Key words Diabetes mellitus, Diabetic retinopathy, Glutathione peroxidase, Lipid peroxidation, Superoxide dismutase, Vitamin C

Free radicals (FR), described as atoms and/or molecules with one or more unpaired electrons in the outer orbit, or in the other words reactive oxygen $\left(\mathrm{O}_{2}\right)$ derivatives, continuously form in aerobic organisms as a result of various metabolic processes. These highly reactive molecules affect biomolecules such as lipids, proteins, nucleic acids and carbohydrates. ${ }^{1,2}$ In order to compensate the effects of FR, there are defence mechanisms in the organism called antioxidants. If the sensitive balance between FR and antioxidant levels is not protected properly, many pathological alterations occur that result in cell damage, and the integrity of the cell and tissue is threatened. In recent years, research related to diseases caused by FR has gained in importance. It is now known that FR play an important role in the pathologies such as cancer, atherosclerosis, diabetes mellitus (DM), Parkinson's disease, heart lesions related to stress, liver pathology, ageing and various types of infectious diseases. These FR are continuously formed in all aerobic cells, and consist of the superoxide radical $\left(\mathrm{O}_{2}^{-}\right)$, hydrogen peroxide $\left(\mathrm{H}_{2} \mathrm{O}_{2}\right)$ and hydroxyl radical $(\mathrm{OH}){ }^{1,2}$ These metabolites are responsible for lipid peroxidation (LPO), which is described as a conglomeration reaction of the polyunsaturated fatty acids found in the cell membrane (phospholipids, glycolipids, glyceride and sterol) to various products such as peroxides, alcohols, aldehydes, hydroxy fatty acids, ethane and pentane. In addition, FR damage DNA, inactivate enzymes and oxidise hormones. ${ }^{1,2}$

Antioxidants, described as substances which prevent or delay oxidative damage in target molecules, may be classified as enzymes or small non-enzymatic protein molecules according to their structure, and as endogenous or exogenous antioxidants according to their source. In the organism there are many enzymes with an antioxidant role, such as superoxide dismutase (SOD), glutathione peroxidase (GSH-Px), catalase, cytochrome oxidase and 
small molecules such as glutathione, melatonin, carotenoids, retinoids and vitamins $C$ and $E$. One of these, SOD, decreases the intracellular $\mathrm{O}_{2}{ }^{-}$level by catalysing its transformation to $\mathrm{H}_{2} \mathrm{O}_{2}$ and $\mathrm{O}_{2}$. GSH-Px reduces $\mathrm{H}_{2} \mathrm{O}_{2}$ and organic hydroperoxides. Vitamin $\mathrm{C}$ is an important component of the cellular defence against LPO and $\mathrm{O}_{2}$ toxicity caused by FR. It suppresses $\mathrm{O}_{2}^{-}$, $\mathrm{OH}$ and singlet oxygen, and reacts with the tocopheroxyl radical to re-form tocopherol, and thus prevent LPO.

It has long been known that there is an imbalance between oxidants and antioxidants in DM. In 1979, Sato et al. ${ }^{3}$ reported that plasma LPO levels of diabetic patients are higher than in normal people, and LPO levels of diabetic patients with angiopathy are higher than in the other diabetic patients without any complications. This has been supported by studies indicating that LPO products increase in the blood of patients with DM (both type I and type II) and also in diabetic rats. ${ }^{4-21}$ Reactive $\mathrm{O}_{2}$ metabolites, including FR, increase with auto-oxidation of glucose and glycosylated proteins in DM, and with the activation of the sorbitol pathway during hyperglycaemia. Insufficient neutralisation of FR causes the oxidation of cellular lipids, proteins, nucleic acids, glycolipids and glycoproteins. ${ }^{7}$ This oxidative effect also causes damage to the vascular endothelial cells. Additionally, prostaglandin synthesis is affected due to oxidation of arachidonic acid, a polyunsaturated fatty acid. Therefore, it is claimed that the long-term complications of DM are related to the accumulation of increased FR and LPO products. $^{3,4,7-9,12-14,16,17,20}$

This study was planned to research the role of oxidative stress in diabetic retinopathy (DR). Three groups of patients were studied: DM cases with DR, DM cases without DR or any angiopathic complication, and healthy individuals. The serum malondialdehyde (MDA)-like metabolites as an index of LPO, erythrocyte GSH-Px and SOD levels and serum vitamin C concentration were determined and the data obtained from these three groups were analysed statistically.

\section{Materials and methods}

This study was carried out on 25 patients with DR (group I), 34 patients with non-insulin-dependent DM (NIDDM) without any angiopathic complication (group II) and 26 healthy subjects (group III). Subjects with DM included in the study were chosen according to the following criteria among the subjects with NIDDM who were under observation in the Internal Medicine Department. A systemic examination of the subjects, all of them normotensive, urine analysis for nephropathy, electrocardiography (ECG) for macrovascular angiopathic complications and peripheral pulse examinations were performed to exclude any subjects from group I who might have any angiopathic complications other than DR. Those subjects with proteinuria detected with urine analysis, postmyocardial infarction and/or ischaemic symptoms detected with ECG or whose peripheral pulse was not taken (confirmed with Doppler ultrasonography) were considered as having angiopathic complications and excluded from the study. Subjects with complaints which may imply diabetic neuropathy such as paresthaesias and foot pain were also not included in the study. In fundus examinations of the dilated pupil with direct and indirect ophthalmoscopy, those with microaneurysms, dot and/or blot haemorrhages, or hard and/or soft exudates were diagnosed as DR and fundus fluorescein angiography (FFA) was carried out with a Canon CF-60UVi. Subjects with DM who had no angiopathic complication were considered as group II. Group III consists of the subjects who presented to the Eye Clinic with no pathology other than a refraction error and had normal results after systemic examinations. Informed consent was obtained from all subjects. A history was taken from all subjects, the time of onset of the disease, and height and weight measurements. Body mass index (BMI) was calculated by using the following equation: $\mathrm{BMI}=$ weight $(\mathrm{kg}) /$ length $\left(\mathrm{m}^{2}\right)$. All subjects were on no other treatment except oral antidiabetics.

Planned biochemical parameters of the subjects who were chosen according to the criteria mentioned above were investigated at our Faculty's Department of Biochemistry Laboratory. Approximately $10 \mathrm{ml}$ of venous blood was taken from the antecubital vein following a $12 \mathrm{~h}$ fast. Five millilitres of the blood was transferred to tubes with heparin for the separation of erythrocytes, and $5 \mathrm{ml}$ to plain tubes for the separation of serum. Plain tubes were kept at room temperature for about $30 \mathrm{~min}$ and then centrifuged for $15 \mathrm{~min}$ at $3000 \mathrm{rpm}$ to separate the serum. LPO was investigated immediately. Heparinised tubes were centrifuged for $10 \mathrm{~min}$ at $3000 \mathrm{rpm}$ to separate plasma. An erythrocyte package was prepared by washing erythrocytes three times with physiological serum. The erythrocyte package was stored at $-20{ }^{\circ} \mathrm{C}$ for GSH-Px and SOD analysis. GSH-Px and SOD activities were measured within a maximum of 2 weeks.

Serum LPO level was measured using Satoh's method based on the reactivity of thiobarbituric acid (TBA). 9,22 MDA creates a coloured complex that gives a maximum absorbance at $532 \mathrm{~nm}$ as it reacts with TBA. MDA is a final product of fatty acid peroxidation and is accepted as a measure of the LPO index. Serum LPO was given as nanomoles MDA per millilitre.

GSH-Px activity was measured with a Hitachi 911 automated analyser using a commercial kit (Randox Lab., UK) in erythrocyte haemolysates. GSH-Px estimation was based on the following principle: GSH-Px catalyses the oxidation of glutathione by cumen hydroperoxide. In the presence of glutathione reductase and NADPH the oxidised glutathione is immediately converted to the reduced form with a concomitant oxidation of NADPH to $\mathrm{NADP}^{+}$. The decrease in absorbance at $340 \mathrm{~nm}$ is measured. This technique is based on the method of Paglia and Valentine. ${ }^{15,19,23}$

Erythrocyte SOD activity was measured in an automated analyser (Hitachi 911) using a commercial kit (Randox Lab., UK). SOD estimation was based on the 
Table 1. Sex, azerage age, body mass index $(B M I)$, HbA li and duration of disease of the groups

\begin{tabular}{|c|c|c|c|c|c|}
\hline & $\operatorname{Sex}(F / M)$ & Age (years) & BMI $\left(\mathrm{kg} / \mathrm{m}^{2}\right)$ & $\mathrm{HBA}_{1,}\left({ }^{\circ}{ }^{\circ} 0\right)$ & Duration of disease (years) \\
\hline $\begin{array}{l}\text { Subjects with retinopathy } \\
\quad \text { (group } 1 ; n=25 \text { ) }\end{array}$ & $17 / 8$ & $54.60 \pm 6.85^{a}$ & $27.58 \pm 4.05$ & $9.14 \pm 1.97^{b}$ & $7.64 \pm 2.89^{d}$ \\
\hline $\begin{array}{l}\text { Subjects without complications } \\
\quad \text { (group II; } n=34 \text { ) }\end{array}$ & $21 / 1.3$ & $51.79 \pm 7.69$ & $26.69 \pm 4.39$ & $8.78 \pm 1.46^{\circ}$ & $3.69 \pm 2.05$ \\
\hline $\begin{array}{l}\text { Healthy subjects } \\
\quad(\text { group III; } n=26)\end{array}$ & $14 / 12$ & $5(0.23 \pm 6.89$ & $25.71 \pm 3.82$ & $4.79 \pm 0.82$ & \\
\hline
\end{tabular}

Values are the average \pm SD.

$a p=0.02$ in group I compared with group III (Mann-Whitney $U$-test); " $p=0.001$ in group I compared with group III; " $p=0.001$ in group II compared with group III (Student's t-test); ' $p=0.0001$ in group I compared with group II (Mann-Whitney U-test).

generation of $\mathrm{O}_{2}{ }^{-}$, produced by xanthine and xanthine oxidase, which reacts with 2-(4-iodophenyl)-3-(4nitrophenol)-5-phenyltetrazolium chloride to form a red formazan dye. The SOD activity is then measured by the degree of inhibition of this reaction. This technique is used by many investigators. ${ }^{15,24-26}$ Enzyme activities were given as units per gram haemoglobin.

Serum vitamin $C$ level was measured using the dinitrophenylhydrazine method. ${ }^{15,27,28}$ Vitamin $C$ in serum is oxidised by $\mathrm{Cu}(\mathrm{II})$ to form dehydroascorbic acid (DHA), which reacts with acidic 2,4-

dinitrophenylhydrazine to form a red bis-hydrazone, which is measured at $520 \mathrm{~nm}$. Ascorbic acid (AA) was also used as a standard and the results were expressed as micromoles per litre.

Results are given as the average $\pm \mathrm{SD}$. For average age and duration of disease analysis, the Mann-Whitney $U$-test in the SPSS package program was used, and for other analysis Student's $t$-test and Spearman correlation tests were used.

\section{Results}

Table 1 shows the sex, age, $\mathrm{BMI}, \mathrm{HbA}_{\mathrm{lc}}$ and duration of disease for 25 subjects with DR of whom 17 were female and 8 male with ages between 42 and 69 years (average $54.60 \pm 6.85$ years); 34 subjects with uncomplicated DM of whom 21 were female and 13 male with ages between 41 and 66 years (average $51.79 \pm 7.69$ years) and 26 healthy subjects of whom 14 were female and 12 male with ages between 41 and 63 years (average $50.23 \pm 6.89$ years).

Regarding the average age of the subjects it was found that although there was no statistically significant difference between groups I and II and between groups II and III $(p>0.05)$, there was a statistically significant difference between groups I and III $(p=0.02)$. Although the BMI of group I was higher than that of the other subjects, there were no statistically significant differences among the groups $(p>0.05)$. Whereas the $\mathrm{HbA}_{1 \mathrm{c}}$ level of group I was slightly higher than that of group II, there were no statistical differences between them $(p>0.05)$. However, the $\mathrm{HbA}_{1 \mathrm{c}}$ levels of both groups were significantly higher than that of the healthy subjects $(p=0.001)$. There was a significant difference $(p=0.0001)$ between the duration of disease in group I (3-16 years) and group II ( 6 months to 8 years) All the subjects in the first group, whose fundus examination and FFA were done, had non-proliferative DR. Table 2 shows LPO, antioxidant enzyme and vitamin $C$ levels of these groups.

LPO assessment of the groups suggested that all subjects with DM showed an increased LPO, and there were statistically significant differences between group I $(4.38 \pm 1.31 \mathrm{nmol} / \mathrm{ml})$ and group II $(3.38 \pm 0.95 \mathrm{nmol} /$ $\mathrm{ml})$, group I and group III $(2.61 \pm 0.85 \mathrm{nmol} / \mathrm{ml})$, and group II and group III $(p=0.0001$ and $p=0.002$, respectively). There was also a positive relationship between the duration of disease and LPO in the correlation analysis $(r=0.36, p=0.047)$. When antioxidant enzyme levels were compared, there were no statistically significant differences among the groups $(p>0.05)$. Vitamin $C$ levels were low in all subjects with DM compared with healthy subjects and there were statistically significant differences between group I $(42.72 \pm 8.90 \mu \mathrm{mol} / \mathrm{l})$ and group II $(49.26 \pm 11.52$ $\mu \mathrm{mol} / \mathrm{l})$, group I and group III $(58.57 \pm 9.75 \mu \mathrm{mol} / \mathrm{l})$ and group II and group III $(p=0.02, p=0.001$ and $p=0.002$, respectively).

Table 2. Serum lipid peroxidation (LPO), erythrocyte glutathione peroxidase (GSH-Px), superoxide dismutase (SOD) and serum zitamin C levels of the groups

\begin{tabular}{|c|c|c|c|c|}
\hline & $\mathrm{LPO}(\mathrm{nmol} / \mathrm{ml})$ & GSH-Px (U/g Hb) & $\mathrm{SOD}(\mathrm{U} / \mathrm{g} \mathrm{H} / \mathrm{b})$ & Vitamin $C(\mu \mathrm{mol} / \mathrm{l})$ \\
\hline $\begin{array}{l}\text { Subjects with retinopathy } \\
\text { (group } 1 ; n=25 \text { ) }\end{array}$ & $4.38=1.31^{a b b}$ & $68.97 \pm 18.04$ & $1597.78 \pm 296.46$ & $42.72 \pm 8.90^{d . t^{\prime}}$ \\
\hline $\begin{array}{l}\text { Subjects without complications } \\
\quad \text { (group II; } n=34 \text { ) }\end{array}$ & $3.38 \pm 0.95^{\circ}$ & $64.30 \pm 19.26$ & $1581.33 \pm 278.08$ & $49.26 \pm 11.2^{f}$ \\
\hline $\begin{array}{l}\text { Healthy subjects } \\
\qquad \text { (group III; } n=26)\end{array}$ & $2.61 \pm 0.85$ & $65.52 \pm 17.58$ & $1587.44 \pm 281.17$ & $58.57 \pm 9.75$ \\
\hline
\end{tabular}

Values are the average \pm SD.

$" p=0.001$ in group I compared with group II; $" p=0.0001$ in group I compared with group III; $" p=0.002$ in group II compared with group III (Student's $t$-test); ${ }^{d} p=0.02$ in group I compared with group II; ${ }^{c} p=0.001$ in group I compared with group III; ${ }^{f} p=0.002$ in group II compared with group III (Student's $t$-test). 


\section{Discussion}

The balance between the production and destruction of oxidants formed in cells and tissues has a vital importance for survival of the structural integrity of tissues. Inclination of the balance to the side of oxidation causes cell damage. LPO products causing oxidative damage are one of the most important endogenous factors that destroy the lipid layers of cell membranes. In the studies on the aetiology of DR, it has been demonstrated that plasma and tissue LPO products in patients with DM were higher than in healthy persons; therefore, it has been proposed that increased oxidative stress is implicated in the aetiology of DM and its longterm complications. ${ }^{3,4,7-9,12-14,16,17,20}$ In our study it was found that serum LPO levels of subjects with DR were higher than in subjects with DM who had no complications and healthy subjects, the differences between the levels being statistically quite significant. Similarly, serum LPO levels of subjects with DM without any complications were higher than the LPO levels of healthy subjects, the differences between the levels again being statistically significant. Our findings were in agreement with those in the literature. ${ }^{3-21}$ The reasons for increased LPO in DM are: increased reactive $\mathrm{O}_{2}$ products as a result of auto-oxidation of glucose and glycosylated proteins, polyol pathways, and decreased non-enzymatic antioxidants. In addition, hyperglycaemia increases the formation of triose phosphate, whose oxidation causes the formation of two free radicals: alpha oxaldehyde and $\mathrm{H}_{2} \mathrm{O}_{2} \cdot{ }^{17}$ The increased levels of lipid peroxides can cause oxidative injury to blood cells, cross-linking of membrane lipids and proteins, increasing of cell ageing, imbalance of prostacyclin/prostaglandin and vasoconstriction. $^{29}$

SOD, which belongs to the metallo-proteinase family, catalyses the dismutation of $\mathrm{O}_{2}^{-}$, into $\mathrm{H}_{2} \mathrm{O}_{2}$. Also GSH-Px has a key role in enzymatic defence systems and acts on peroxides $\left(\mathrm{H}_{2} \mathrm{O}_{2}\right.$ lipid or organic peroxides) to remove them. In the literature, different results have been reported in different organs and tissues regarding the levels of these two enzymes in DM (human and experimental). ${ }^{15,18,30-34}$ In our study, the erythrocyte SOD and GSH-Px values were quite similar in each group. Different results were also reported in the literature regarding the levels of these two enzymes in the erythrocytes of DM subjects. In some studies ${ }^{18,30,35,36}$ the erythrocyte SOD levels were low, but in others they were normal $^{11}$ or high. ${ }^{37,38}$ While in the study by Hagglof $e t$ $a .^{39}$ the SOD and GSH-Px activities were low, in the study by Sundaram et al. ${ }^{17}$ the SOD activity was low and GSH-Px activity was high. In accordance with our study, Ruiz et al. ${ }^{21}$ Jos et al. ${ }^{40}$ and Walter et al. ${ }^{41}$ also found the erythrocyte SOD and GSH-Px activities similar in DM and healthy subjects. It is not clear to us whether these different results are based on different assay methods or compensatory mechanisms, or on other factors such as age, duration of diabetes and diabetic state. According to the authors who found antioxidant enzyme levels low in $\mathrm{DM}$, because of the inactivation of the antioxidant enzymes by non-enzymatic glycation due to persistent hyperglycaemia as shown with SOD by Arai et al., ${ }^{36}$ the oxidative stress increase also depends on the insufficiency of the antioxidant defence system, among other reasons.

Vitamin C, which is a water-soluble vitamin and the most important antioxidant vitamin, inactivates FR found in the cytosol, plasma and extracellular environment. It is reported that when the FR in plasma increases, LPO can not occur until all the AA present in the environment has been oxidised. ${ }^{10}$ In healthy tissue AA always turns to DHA, which returns to AA. If the regeneration of DHA to $\mathrm{AA}$ can not occur, that means if the AA/DHA ratio decreases, the antioxidant capacity of the tissue decreases and oxidative damage develops. In our study, we detected serum AA levels significantly lower in all DM patients than healthy subjects. In addition, we found that AA levels of the DR group were lower than those of the DM group who had no complications. This result was confirmed by both human and animal experiments..$^{9,17,28,42-45}$ Sinclair et al. ${ }^{9,43}$ reported that serum AA levels were lower than in controls, and even lower in DM cases with microangiopathy. They also emphasised that the ratio of AA to DHA in DM patients with microangiopathy decreased compared with both DM patients without microangiopathy and control groups. Similarly, in the study by Sundaram et al. ${ }^{17}$ it was shown that in DM when the severity and number of secondary angiopathic complications increased, the levels of serum vitamin C gradually decreased. The decreased AA level in DM may be explained by (a) the enhanced consumption of AA as a result of increased oxidation of AA to DHA to scavenge increased $\mathrm{FR}^{43,45}$ and (b) failed regeneration of $\mathrm{AA}$ from DHA. Intracellular regeneration of AA from DHA may be impaired because of competitive inhibition of its transport across the cell membrane by glucose, a structurally similar molecule. ${ }^{44,46}$

We have determined a positive relation between LPO levels and the duration DM. The longer the duration of $\mathrm{DM}$, the higher the LPO levels (which means more oxidative stress); this finding shows a parallelism with the fact that the possibility of DR increases with the duration of $\mathrm{DM}^{47}$ This finding was also emphasised by Sundaram et al. ${ }^{17} \mathrm{FR}$ in the blood may have a direct cytotoxic effect on the endothelial cells and cause cellular trauma. ${ }^{16,48}$ Moreover it was reported that $\mathrm{O}_{2}{ }^{-}$and $\mathrm{OH}$ increased in the vessel walls of DM and thus the endothelium-dependent vasodilatation may be impaired in diabetes. ${ }^{14,49,50}$ Beside this, inhibition of the biosynthesis of prostacyclin by lipid peroxides causes vasoconstriction and proaggregant effects of thromboxane, so that there may be a tendency to thrombosis. ${ }^{16}$

Endothelial cell destruction has an important role in microvascular obstruction and leakage, which are basic pathologies of DR. When it is considered that even a slight trauma to the endothelial cells of an artery is effective in atherogenesis, ${ }^{48}$ in DM, where such trauma occurs chronically and increases over time as a result of 
the effects of LPO products, it is obvious that oxidative stress plays an important role in the development of vascular complications.

In conclusion, this study demonstrates significant abnormalities in oxidant-antioxidant mechanisms in DM. It was found that the circulating levels of LPO and vitamin $C$ in patients with DR were higher than in subjects with DM who had no complications and in healthy subjects, and that there is a positive correlation between LPO levels and the duration of DM. In the light of our findings and additional data in the literature, we emphasise that FR, which increasingly are produced in $\mathrm{DM}$, may play a significant role in the development of $\mathrm{DR}$, one of the important complications of DM.

\section{References}

1. Halliwell B. Free radicals, antioxidants, and human disease: curiosity, cause, or consequence? Lancet 1994;344:721-4.

2. Freeman BA, Crapo JD. Biology of disease, free radicals and tissue injury. Lab Invest 1982;47:412-26.

3. Sato Y, Hotta N, Sakamoto N, Matsuoka S, Ohishi N, Yagi K. Lipid peroxide level in plasma of diabetic patients. Biochem Med 1979;21:104-7.

4. Jennings PE, Jones AF, Florkowski CM, Lunec J, Barnett AH. Increased diene conjugates in diabetic subjects with microangiopathy. Diabet Med 1987;4:452-6.

5. Jain SK, McVie R, Duett J, Herbst JJ. Erythrocyte membrane lipid peroxidation and glycosylated hemoglobin in diabetes. Diabetes 1989;38:1539-43.

6. Jain SK, Levine SN, Duett J, Hollier B. Elevated lipid peroxidation levels in red blood cells of streptozotocintreated diabetic rats. Metabolism 1990;39:971-5.

7. Baynes JW. Perspective in diabetes. Role of oxidative stress in development of complication in diabetes [Review]. Diabetes 1991;40:405-12.

8. Lyons TJ. Oxidised low density lipoproteins: a role in the pathogenesis of atherosclerosis in diabetes? Diabet Med 1991;8:411-9.

9. Sinclair AJ, Girling AJ, Gray L, Lunec J, Barnett AH. An investigation of the relationship between free radical activity and vitamin $\mathrm{C}$ metabolism in elderly diabetic subjects with retinopathy. Gerontology 1992;38:268-74.

10. Young IS, Torney JJ, Trimble ER. The effect of ascorbate supplementation on oxidative stress in the streptozotocin diabetic rat. Free Rad Biol Med 1992;13:41-6.

11. Faure P, Corticelli P, Richard MJ, Arnaud J, Coudray C, Halimi S, et al. Lipid peroxidation and trace element status in diabetic ketotic patients: influence of insulin therapy. Clin Chem 1993;39:789-93.

12. Augustin AJ, Breipohl W, Böker T, Lutz J, Spitznas M. Increased lipid peroxide levels and myeloperoxidase activity in the vitreous of patients suffering from proliferative diabetic retinopathy. Graefes Arch Cli Exp Ophthalmol 1993;231:647-50.

13. Gallau G, Ruelland A, Legras B, Maugendre D, Allannic H, Cloarec L. Plasma malondialdehyde in type I and type II diabetic patients. Clin Chim Acta 1993;214:227-34.

14. Giugliano D, Ceriello A, Paolisso G. Oxidative stress and diabetic vascular complications. Diabetes Care 1996;19:257-67.

15. Akkuş I, Kalak S, Vural H, Cağlayan O, Menekşe E, Can G, et al. Leukocyte lipid peroxidation, superoxide dismutase, glutathione peroxidase and serum and leukocyte vitamin C levels of patients with type II diabetes mellitus. Clin Chim Acta 1996;244:221-7.
16. Losada M, Alio JL. Malondialdehyde serum concentration in type I diabetic with and without retinopathy. Doc Ophthalmol 1996;93:223-9.

17. Sundaram RK, Bhaskar A, Vijayalingam S, Viswanathan M, Mohan R, Shanmugasundaram KR. Antioxidant status and lipid peroxidation in type II diabetes mellitus with and without complications. Clin Sci 1996;90:255-60.

18. Yadav P, Sarkar S, Bhatnagar D. Lipid peroxidation and antioxidant enzymes in erythrocytes and tissues in aged diabetic rats. Indian J Exp Biol 1997;35:389-92.

19. Yadav P, Sarkar S, Bhatnagar D. Action of Capparis decidua against alloxane-induced oxidative stress and diabetes in rat tissues. Pharmacol Res 1997;36:221-8.

20. Verdejo C, Marco P, Renau-Piqueras J, Pinazo-Duran MD. Lipid peroxidation in proliferative vitreoretinopathies. Eye 1999;13:183-8.

21. Ruiz C, Barbera AR, Farre R, Lagarda MJ. Lipid peroxidation and antioxidant enzyme activities in patients with type I diabetes mellitus. Scand J Clin Lab Invest 1999;59:99-106.

22. Satoh K. Serum lipid peroxide in cerebrovascular disorders determined by a new colorimetric method. Clin Chim Acta 1978;90:37-43.

23. Paglia DE, Valetine WN. Studies on the quantitative and qualitative characterization of erythrocyte glutathione peroxidase. J Lab Clin Med 1967;70:158-63.

24. Flohe BL, Otting F. Superoxide dismutase assays. Methods Enzymol 1984;105:93-104.

25. Spitz DR, Oberley LW. An assay for superoxide dismutase activity in mammalian tissue homogenates. Anal Biochem 1989;179:8-18

26. Guemouri L, Artur Y, Herbeth B. Biological variability of superoxide dismutase, glutathione peroxidase, and catalase in blood. Clin Chem 1991;37:1932-7.

27. Omaye ST, Turnbull JD, Sauberlich HE. Selected methods for the determination of ascorbic acid in animal cells, tissues, and fluids. Methods Enzymol 1979;62:3-11.

28. Stankova L, Riddle M, Larned J, Burry K, Menashe D, Hart J. et al. Plasma ascorbate concentrations and blood cell dehydroascorbate transport in patients with diabetes mellitus. Metabolism 1984;33:347-53.

29. Jain SK, McVie R, Jaramillo JJ, Palmer M, Smith T, Meachum $\mathrm{ZD}$, et al. The effect of modest vitamin E supplementation on lipid peroxidation products and other cardiovascular risk factors in diabetic patients. Lipids 1996;31(Suppl):87-90.

30. Loven D, Schedl H, Wilson H, Daabees TT, Stegink LD, Diekus $\mathrm{M}$, et al. Effect of insulin and oral glutathione on glutathione levels and superoxide dismutase activities in organs of rats with streptozotocin-induced diabetes. Diabetes 1986;35:503-7.

31. Godin DV, Wohaieb SA, Garnett ME, Goumeniouk AD. Antioxidant enzyme alterations in experimental and clinical diabetes. Mol Cell Biochem 1988;84:223-31.

32. Pereira B, Rosa LFB, Safi DA, Bechara EJH, Curi R Superoxide dismutase, catalase and glutathione peroxidase activities in the lymphoid organs of diabetic rats. J Endocrinol 1994;142:161-5.

33. Pieper GM, Jordan M, Dondlinger LA, Adams MB, Roza AM. Peroxidative stress in diabetic blood vessels: reversal by pancreatic islet transplantation. Diabetes 1995;44:884-9.

34. Kamata K, Kobayashi T. Changes in superoxide dismutase mRNA expression by streptozotocin-induced diabetes. Br J Pharmacol 1996;119:583-9.

35. Crouch R, Kimsey G, Priest DG, Sarda A, Buse MG. Effect of streptozotocin on erythrocyte and retinal superoxide dismutase. Diabetologia 1978;15:53-7.

36. Arai K, Lizuka S, Tada Y, Oikawa K, Taniguchi N. Increase in the glucosylated form of erythrocyte $\mathrm{Cu}-\mathrm{Zn}$-superoxide dismutase in diabetes and close association of the nonenzymatic glucosylation with the enzyme activity. Biochim Biophys Acta 1987;924:292-6. 
37. Kawamura N, Ookawara T, Suzuki K, Konishi K, Mino M, Taniguchi $\mathrm{N}$. Increased glycated $\mathrm{Cu}, \mathrm{Zn}$-superoxide dismutase levels in erythrocytes of patients with insulindependent diabetes mellitus. J Clin Endocrinol Metab 1992;74:1352-4.

38. Strange RC, Jones P, Bicknell J, Scarpello J. Expression of $\mathrm{Cu}, \mathrm{Zn}$-superoxide dismutase and glutathione peroxidase in erythrocytes from diabetic and non-diabetic subjects. Clin Chim Acta 1992;207:261-3.

39. Hagglof B, Marklund SL, Holmgren G. Cu/Zu-superoxide dismutase, Mn-superoxide dismutase, catalase and glutathione peroxidase in lymphocytes and erythrocytes in IDDM. Acta Endocrinol 1983;102:235-9.

40. Jos J, Rybak M, Patin PH, Robert JJ, Boitard C, Thevenin R. Antioxidant enzymes in insulin-dependent diabetes in the child and adolescent. Diabetes Metab 1990;16:498-503.

41. Walter RM, Uriu-Hare JY, Olin KL, Oster MH, Anawalt BD, Critchfield JW, et al. Copper, zinc, manganese, and magnesium status and complications of diabetes mellitus. Diabetes Care 1991;14:1050-6.

42. McLennan S, Yue DK, Fisher E, Capogreco C, Hefferman S, Ross GR, et al. Deficiency of ascorbic acid in experimental diabetes: relationship with collagen and polyol pathway abnormalities. Diabetes 1988;37:359-61.

43. Sinclair AJ, Girling AJ, Gray L, Le Guen C, Lunec J, Barnett $\mathrm{AH}$. Disturbed handling of ascorbic acid in diabetic patients with and without microangiopathy during high dose ascorbate supplementation. Diabetologia 1991;34:171-5.
44. Maxwell SRJ, Thomason H, Leguen DSC, Baxter MA, Thorpe $\mathrm{GHG}$, Jones AF, et al. Antixodant status in patients with uncomplicated insulin-dependent and non-insulindependent diabetes mellitus. Eur J Clin Invest 1997;27:484-90.

45. Sun F, Iwaguchi K, Shudo R, Nagaki Y, Tanaka K, Ikeda K, et al. Change in tissue concentrations of lipid hydroperoxides, vitamin $\mathrm{C}$ and vitamin $\mathrm{E}$ in rats with streptozotocin-induced diabetes. Clin Sci 1999;96:185-90.

46. Bigley R, Wirth M, Layman D, Riddle M, Stankova L. Interaction between glucose and dehydroascorbate transport in human neutrophils and fibroblasts. Diabetes 1983;32:545-8.

47. Kanski JJ. Diabetic retinopathy: Retinal vascular disorders. In: Kanski JJ, editor. Clinical ophthalmology. London: Butterworth-Heinemann, 1992;300-37.

48. Yagi K. Lipid peroxides and human disease. Chem Phys Lipids 1987;45:337-51.

49. Pieper GM, Langenstroer P, Siebeneich W. Diabetic-induced endothelial dysfunction in rat aorta: role of hydroxyl radicals. Cardiovasc Res 1997;34:145-56.

50. Manas-Rodrigues L, Angulo J, Peiro C, Llergo JL, SanchezFerrer A, Lopez-Doriga P, et al. Endothelial dysfunction and metabolic control in streptozotocin-induced diabetic rats. Br J Pharmacol 1998;123:1495-502. 